\title{
Right-Wing Extremism and the Well-Being of Immigrants
}

\author{
Andreas Knabe* \\ Otto-von-Guericke-University Magdeburg and CESifo \\ Steffen Rätzel \\ Otto-von-Guericke-University Magdeburg \\ Stephan L. Thomsen ${ }^{* * *}$ \\ Leibniz University Hannover, NIW Hannover, and ZEW Mannheim
}

May 2013

\begin{abstract}
This study analyzes the effects of right-wing extremism on the well-being of immigrants based on data from the German Socio-Economic Panel (SOEP) for the years 1984 to 2006 merged with state-level information on election outcomes. The results show that the life satisfaction of immigrants is significantly reduced if right-wing extremism in the native-born population increases. Moreover, the life satisfaction of highly educated immigrants is affected more strongly than that of low-skilled immigrants. This supports the view that policies aimed at making immigration more attractive to the high-skilled have to include measures that reduce xenophobic attitudes in the native-born population.
\end{abstract}

JEL Classification Codes: I31, R23, J15

Keywords: Well-Being, Life Satisfaction, Right-Wing Extremism, Migration, SOEP

Otto-von-Guericke-University Magdeburg, Faculty of Economics and Management, P.O. Box 4120, 39016 Magdeburg, Germany. E-mail: andreas.knabe@ovgu.de.

*** Leibniz University Hannover and Niedersächsisches Institut für Wirtschaftsforschung, Königstr. 53, 30175 Hannover, Email: thomsen@niw.de.

Stephan L. Thomsen thanks the Stifterverband für die Deutsche Wissenschaft (Claussen-Simon-Stiftung) for financial support. The data used in this publication were made available by the German Socio-Economic Panel Study (SOEP) at the German Institute for Economic Research (DIW), Berlin. 


\section{INTRODUCTION}

Immigration from developing countries to developed economies can generate substantial positive effects for the host countries. One of the reasons is that the growth of the labor force in developed countries is expected to slow down, and that the labor force will eventually decline, within the next 20 years. This will lead to rising elderly dependency ratios, which puts a strain on public budgets. Migration, in particular the immigration of skilled workers, could help to mitigate the fiscal cost of a rapidly aging population (cf. World Bank 2006). Hence, many developed countries have implemented selective migration policies, using systems of quotas, points, and targeted programs (cf. OECD 2007). The European Union is also pursuing plans to create an "EU Blue Card". This program is supposed to make immigration to the EU more attractive for highly qualified workers by creating a fast-track to obtain work permits and by granting favorable conditions for family reunification and movement across the EU. As these examples show, attracting high-skilled workers is one of the core aims of immigration policies in developed economies.

In Germany, the situation appears to be even more dramatic than in other developed economies. The share of the working-age population has already been shrinking since the 1980s. Without immigration, the German Statistical Office expects the elderly dependency ratio to rise from 45.2 (people $\geq 60$ years per 100 persons aged 20-59) in 2005 to 101.3 in 2050 (Statistisches Bundesamt 2006). Examining the interplay of immigrants' economic performance and immigration policy in various European countries, Constant and Zimmermann (2005) find that, in particular, Germany could benefit from targeting its integration policies more at high-skilled immigrants.

Despite the potential benefits of immigration to developed economies, public opinion with respect to immigration has deteriorated in the face of high unemployment and strained welfare systems in many European countries. Native populations are concerned that migrants, as recipients of generous social transfers, are more of a fiscal burden than contributors to the domestic economy. Although there are differences between member states in the EU25 and between different socio-demographic groups with regard to the types of fear and concerns, Beutin et al. (2006) note in their overview that despite these differences the public perception of migration tends to be increasingly negative throughout Europe.

An extreme manifestation of this development is the growing prevalence of right-wing and xenophobic political attitudes and increasing support for right-wing political parties among 
native populations. In Germany, the number of right-wing extremists has more than doubled between 1990 and 2005 (Siedler 2011). The number of violent and non-violent right-wing crimes has increased accordingly.

Anti-foreign sentiments in the host population may deter economically beneficial immigration. If certain regions of a country are (in)famous for xenophobic attitudes of the native population, immigrants may leave these areas or people may be deterred from moving into those regions. In a recent survey among 300 German companies (Bussmann and Werle 2004), 5 (11) percent of West (East) German firms reported that regional xenophobia and right-wing violence already had an impact on their business, and 17 (28) percent of all firms expect that these factors could influence future business decisions (again). Up to 40 percent of all firms stated that xenophobia in the region affected their recruitment strategies. 4 (11) percent of West (East) German firms reported that prospective employees declined job offers explicitly because of fear of xenophobia in the firm's region, and even more firms suspect that the prevalence of right-wing attitudes is the real reason behind declined job offers. Bussmann and Werle (2004) also show that firms with R\&D departments are especially sensitive to right-wing extremism because they rely on high-skilled international personnel. This illustrates that right-wing extremism may hamper economic growth by limiting the attractiveness of regions, especially for high-skilled migrants.

In this paper, we want to study how xenophobia and right-wing extremism affect a region's attractiveness for migrants with different skill levels. As a measure for the prevalence of xenophobia in a region and this region's attractiveness for (high-skilled) immigration, we use the share of votes received by political parties on the extreme right in parliamentary elections at the state level and the life satisfaction of (high-skilled) migrants living in the respective state. Of course, right-wing parties address many issues besides racism and xenophobia. Many of these parties also articulate people's fear of economic changes or their resentments towards political elites. By using data from the European Social Survey, however, Ivarsflaten (2005, 2008) shows that no populist right party in Europe was successful without mobilizing grievances over immigration, and that only their aversion to immigration unites all these parties. Although only a small fraction of the population actually votes for right-wing parties in Germany (about 2-4 percent, on average), the share of the population with xenophobic attitudes is much larger (see Siedler 2011). Variations in the vote shares of the far-right can thus be interpreted as representing much larger shifts in the prevalence of right-wing attitudes in the general population. 
The empirical analysis is based on data from the German Socio-Economic Panel (SOEP) for the years 1984 to 2006 merged with state-level information on election outcomes. We estimate how the voting behavior of the residents' population affects immigrants' life satisfaction. Using data on right-wing voting behavior has two advantageous features for the question at hand: first, it is an exogenous variable in the estimation of foreigners' lifesatisfaction because foreigners are not allowed to vote in Germany; second, it provides a good approximation of right-wing attitudes in the native-born population that is not influenced by subjective perceptions reported by the migrants themselves.

Our paper contributes to the existing literature in the following respects. First, this study explores the effects of right-wing extremism of the host country's population on the wellbeing of immigrants. Thus, it extends existing studies that restrict their attention to the resident population when analyzing attitudes towards immigration and related issues. Second, by distinguishing between high-skilled and low-skilled immigrants, we are able to analyze to what extent recent policy reforms that aim at increasing the share of high-skilled immigrants through targeted immigration programs are offset by deterrent right-wing attitudes.

Our results show that migrants in Germany experience, on average, lower life-satisfaction than non-migrants. We also find that the life satisfaction of immigrants is significantly reduced if right-wing attitudes in the native-born population increase, i.e. higher vote shares for the extreme right are associated with lower subjective well-being of immigrants. The results are robust to changes in the estimation method applied or the specification of the model. Moreover, we can clearly establish an educational effect: the life satisfaction of highly educated immigrants is affected more strongly by right-wing attitudes of the host population than that of low-skilled immigrants. This supports the view that policies aimed at making immigration more attractive to the high-skilled have to include measures that reduce xenophobic attitudes in the native-born population.

The paper is structured as follows. The next section presents a review of the relevant literature. In section 3, we present the empirical methodology. Section 4 contains a description of the data and the empirical results are provided in section 5. The final section concludes. 


\section{RELATED LITERATURE}

Xenophobia and other hostile attitudes to immigrants and issues related to immigration are potentially important determinants of the social exclusion and the welfare of ethnic minorities. They may reduce the life satisfaction of immigrants, on the one hand, indirectly through their impact on the political process (e.g. represented by votes, laws and prejudices), and, on the other hand, directly through experiences of personal hostility (Dustmann and Preston, 2001). From an economic perspective, this may result in reduced economic performance of the immigrants and may affect the patterns of migration inasmuch as people may fear to move to certain locations or decide to leave those areas. In addition, anti-foreign sentiments may limit a region's attractiveness for business investment, reducing economic growth and trade (Siedler 2011).

Previous research on attitudes to immigration has focused on the native population. Fertig and Schmidt (2011) study the perceptions of native-born Germans with respect to foreigners and Jews using data of the 1996 ALLBUS survey (a large German opinion survey). Based on the estimation of a structural model to take account of unobserved heterogeneity, their results show that perceptions only depend on the level of education (where those with better education have a more positive attitude), while labor market situation or age turn out to be insignificant. A similar question is analyzed by Dustmann and Preston (2001, 2005). In their 2001 study (based on the British Social Attitudes Survey), they estimate the determinants of attitudes of ethnic majority populations towards ethnic minorities in England using ethnic concentration in the region as the variable of interest. To take account of ethnic concentration in the locality, which may be a determinant, but also an outcome, of the attitudes of the majority population, they suggest the use of a spatial estimator. Their results indicate that high concentrations of ethnic minorities could lead to more hostile attitudes, but that the relationship will be overestimated if the endogeneity of ethnic concentration is not addressed seriously in the estimation. In addition, Dustmann and Preston (2005) analyze the effects of labor market competition, which is frequently perceived as one of the main driving forces determining public attitudes towards immigration. In particular, they hypothesize that those for whose skills immigrant labor is likely to be a substitute may oppose immigration whereas those for whose skills it is complementary may view immigration more sympathetically. Moreover, they argue that the formation of opinions and attitudes towards immigration should be addressed with a broadening of the economic argument: not only factors relating to labor 
market competition, but also factors relating to the public budget and economic efficiency considerations should be taken into account. Based on data from the European Social Survey (ESS), their estimates show a strong relationship between education and more positive attitudes towards various issues relating to migration.

Other studies analyze the determinants of right-wing extremism. Krueger and Pischke (1997) investigate the causes of crime against foreigners in Germany shortly after German unification based on a regional analysis (county-level) where anti-foreign incidents are collected from newspaper recordings. Their results show clear differences in the incident rates between East and West Germany; in the East, incidents occur mostly in rural regions farther from the western part, in the West, incidents occur in urban/metropolitan areas. Moreover, the incidence of anti-foreigner crime is unrelated to the unemployment rate in the region (as a proxy for local economic conditions) when controlling for East-West differences. This is similar to findings for the US, e.g. Land et al. (1990). Although the findings of Krueger and Pischke (1997) indicate no direct connection between violence against foreigners and poor economic conditions in the East, the authors are cautious with respect to the robustness of their findings as the relationship between both may be more complex. Falk and Zweimüller (2011) reinvestigate a closely related question using a larger data base covering official recordings of violent and non-violent crime against foreigners. In particular, using state-level monthly data, they analyze empirically whether unemployment plays a crucial role for the occurrence of right-wing extremist crime, allowing for a non-linear effect of the unemployment rate. The results support the supposed non-linear relationship, i.e. if the unemployment rate is above the median, the number of non-violent crimes increases significantly; however, similar to the findings of Krueger and Pischke (1997), they could not establish comparable results with respect to violent crimes. In a recent paper, Siedler (2011) studies the driving forces behind right-wing extremism with a particular focus on family background and intergenerational transmission of values. His analysis examines the effects of paternal and maternal unemployment during a person's childhood on right-wing attitudes and behavior later in life. Right-wing extremism is measured by information on the affinity to right-wing parties, participation in right-wing extremist groups, and anti-foreign sentiments. His results establish a strong and positively significant association between parental unemployment and various right-wing extremist outcomes for young Germans.

This summary of related studies indicates that the responses of the native population to immigration have received a lot of attention but analyses of the well-being of the immigrants 
themselves are scarce in the economic literature. Sociological research, however, provides some evidence. A thorough analysis of immigrants' life satisfaction in 13 European countries based on three waves of the ESS is provided by Safi (2010). In the empirical analysis, she tests two hypotheses. The first is the so-called assimilation paradigm. Immigrants are expected to assimilate into the host country's population over time (see e.g. Chiswick, 1978, and Borjas, 1985). Hence, one would expect to measure lower levels of life-satisfaction of immigrants, compared to that of natives, shortly after arrival in the host country, but differences should diminish with immigrants' length of stay. In contrast to that, the second hypothesis assumes discrimination. Here, assimilation is assumed to be not only a matter of time. Instead, the host society also plays an active role through mechanisms of discrimination against some groups of immigrants. The hostility immigrants may experience in the receiving society not only solidifies their inferior position but also has a detrimental effect on their psychological well-being. The discrimination hypothesis predicts persisting differences in life satisfaction levels between immigrants and natives that would be more salient for the most stigmatized groups. Safi's (2010) results suggest that there is no improvement of immigrants' well-being over time; even after more than 20 years spent in the host country immigrants still report significantly lower life satisfaction than natives. When self-reported perceived discrimination is controlled for, almost all coefficients of the ethnic variables decrease in magnitude or become statistically insignificant. Non-European immigrants, especially Africans, Turkish or Asians, seem to experience a lower life satisfaction directly related to their perception of discrimination. Thus, discrimination damages immigrants' well-being and strongly accounts for their lower levels of life satisfaction.

\section{METHODOLOGY}

For the empirical analysis, we use the first 23 waves (1984-2006) of the SOEP. The data were extracted using the Add-On-package PanelWhiz for STATA (Haisken-DeNew and Hahn, 2006). We include all individuals residing in West Germany (incl. Berlin) and aged between 18 and 65 . We restrict the sample to West Germany, since in 2008 only 3.5 percent of all immigrants living in Germany were residing in the East (Statistisches Bundesamt 2008), and because data for East Germany is only available since 1991. The age interval was chosen in order to evaluate the effects of right-wing extremism on the well-being of the working-age 
population in particular. Panel attrition in the SOEP is fairly low. For a detailed analysis of the attrition rate and its causes, see Kroh and Spieß (2006).

The focus of our study is the effect of right-wing attitudes in the native-born population on the well-being of immigrants. We divide the sample into two subgroups according to citizenship: persons with German citizenship ("non-migrants") and persons living legally in Germany who are not German citizens ("migrants"). This yields an unbalanced panel with roughly 160,000 observations for non-migrants and about 38,000 observations for migrants. As an alternative, we also divided the sample into a subgroup of people without any migration background and a subgroup of (legal) first-generation immigrants. This alternative division does not change any of our results qualitatively. For second generation migrants, however, we do not find robust effects of right-wing votes on life satisfaction. This suggests that the second generation is already better integrated in the society than the first generation.

Our dependent variable is life satisfaction, which is measured on a 0 to 10 scale (where 0 denotes "not satisfied at all" and 10 stands for "completely satisfied"). In order to explain life satisfaction, we use a set of socio-demographic variables covering employment status, net household income, marital status, and level of education. Further individual heterogeneity is taken into account with a number of personal control variables comprising a person's age, number of children, and having a household member in need of care. Finally, to control for other regional factors that may affect well-being we also include state-level GDP per capita and the state-level unemployment rate as control variables.

For our study, we need a measure for the prevalence of right-wing and xenophobic attitudes at the regional level. As a proxy, we use state-level election results from elections to the federal parliament (Bundestag) and state legislatures (Landtage). ${ }^{1}$ Our measure of right-wing attitudes is the combined share of all votes given to any of the four major German right-wing parties (Deutsche Volksunion, Republikaner, Nationaldemokratische Partei Deutschlands, Partei Rechtsstaatlicher Offensive) in the respective state at the last federal or state election. The Deutsche Volksunion (DVU), the Republikaner (REP), the Nationaldemokratische Partei Deutschlands (NPD), and the Partei Rechtsstaatlicher Offensive (Schill-Partei - named after its founder Ronald Schill; dissolved in 2007) represent the far right of the Germany party

\footnotetext{
${ }^{1}$ Using right-wing votes to approximate right-wing or xenophobic attitudes is also supported by the literature analyzing motives of voting. Based on data for Germany, Carlsson and Johansson-Stenman (2010, p. 509) show "a clear pattern that the more right-wing a person is, the less unethical he/she will perceive selfish voting to be". Put differently, right-wing votes may be interpreted as a direct expression of individual attitudes.
} 
system. They postulate nationalistic and racist ideas against racial, ethnic or religious minorities, especially against foreigners. The German domestic intelligence agency (Verfassungsschutz) observes the activities of the $D V U$, the $N P D$, and parts of the REP because they are considered a threat to the "free and democratic basic order of the Federal Republic of Germany" (Verfassungsschutz, 2008). It should be noted, however, that our findings are not very sensitive to the specific selection of right-wing parties. Leaving out the $D V U, N P D$, or the Schill-Partei does not affect our results qualitatively. Only if the Republikaner are left out, our estimated coefficients change their signs and lose their statistical significance. However, it is not surprising that taking changes in the support for the Republikaner into account is especially important for our study because it is by far the largest of the right-wing parties examined in our study (on average, this party has received more votes than the other parties combined). Variations of the vote share of the smaller parties alone are less informative about the general attitudes of the population. ${ }^{2}$ Since we know the precise date a person was interviewed, we can match each observation to the closest past election in the respective state. Using election results has the advantage that they are strictly exogenous for foreigners because they are not eligible to vote.

To estimate the effects of right-wing extremism on the well-being of immigrants, we estimate the following equation:

$$
L S_{i t}=\alpha_{i}+\beta_{1} R W_{i t}+\gamma^{\prime} X_{i t}+\mu_{t}+\varepsilon_{i t}
$$

where $L S_{i t}$ denotes person $i$ 's life satisfaction at time $t, \alpha_{i}$ is an individual fixed effect that takes account of time-invariant individual unobserved heterogeneity, and $R W_{i t}$ represents the percentage of votes given to right-wing parties in the preceding federal or state election in the person's state of residence. The vector $X_{i t}$ denotes the set of control variables that may potentially be correlated with individual well-being. $\mu_{t}$ represents the year dummies, and $\varepsilon_{i t}$ is a random error term. Since we are interested in the differential effect of right-wing extremism on migrants and non-migrants, we estimate equation (1) for both groups separately.

\footnotetext{
${ }^{2}$ We also tested for influential observations. To see whether a few elections with very high outcomes for RW parties drive our results, we sorted all individual observations according to their RW vote share and dropped the highest five percent. The results for this subsample were qualitatively the same as those for the full sample. We also tested whether our results change when we leave out single Länder. This was not the case.
} 
We have two prior hypotheses regarding equation (1):

$\mathrm{H} 1: \beta_{1}^{\text {migrant }}<0$

Migrants are less satisfied with their life when the prevalence of right-wing extremism in their state of residence increases.

$\mathrm{H} 2: \beta_{1}^{\text {migrant }}<\beta_{1}^{\text {non-migrant }}$ While there is a negative effect of right-wing extremism on migrants' life satisfaction (H1), the effect on non-migrants is weaker (if negative) and might even be positive.

The second question we want to answer empirically is whether the effects of right-wing attitudes in the host society vary with the immigrants' level of education. In light of the recent changes in immigration law in order to increase recruitment of high-skilled foreigners, this question has important consequences for the effectiveness of such migration schemes if there are strong anti-foreign, xenophobic sentiments in the native-born population. If the life satisfaction of high-skilled immigrants reacts more strongly than that of foreigners with lower skills, this could have substantial economic consequences. ${ }^{3}$ These would apply to other countries trying to attract high-skilled foreign workers as well (such as the US or Australia; see Bauer et al., 2011, for an overview of the different attempts).

To test for the right-wing influence on the life satisfaction of the better-educated foreigners, we estimate the following specification:

$$
L S_{i t}=\alpha_{i}+\beta_{1} R W_{i t}+\beta_{2}\left(R W_{i t} \cdot H_{i g h E d u c}\right)+\beta_{3} H_{i g h E d u c}+\gamma^{\prime} X_{i t}+\mu_{t}+\varepsilon_{i t}
$$

where HighEduc $c_{i t}$ is a dummy variable with value 1 if the individual has an education time of more than 11 years (corresponding to a German high school diploma or a leaving qualification from an intermediary school plus vocational training) and 0 otherwise. Hence the interaction term with $R W_{i t}$ describes the effect of an increase in right-wing votes on highly educated individuals in addition to the effect of $\beta_{1}$. If highly-skilled migrants' life satisfaction is more affected, right-wing attitudes and the resulting voting behavior could cause high

\footnotetext{
${ }^{3}$ Guven (2011), for example, shows evidence that supports the hypothesis that a causal link from happiness to social capital exist,
} 
economic costs and would operate against many industrialized countries' efforts to increase immigration of high-skilled workers.

Table 1: Vote shares received by right-wing parties, by state (1983-2008)

\begin{tabular}{l|ccc|ccc}
\hline \hline \multirow{2}{*}{ state } & \multicolumn{3}{|c}{ federal elections } & \multicolumn{3}{c}{ state elections } \\
& $\operatorname{mean}$ & $\max$ & $\min$ & $\operatorname{mean}$ & $\max$ & $\min$ \\
\hline Berlin & $2.9 \%$ & $4.9 \%$ & $1.9 \%$ & $3.2 \%$ & $7.5 \%$ & $0.0 \%$ \\
Schleswig- Holstein & $1.2 \%$ & $2.0 \%$ & $0.2 \%$ & $2.4 \%$ & $7.5 \%$ & $0.0 \%$ \\
Hamburg & $1.8 \%$ & $4.5 \%$ & $0.2 \%$ & $4.7 \%$ & $20.2 \%$ & $0.0 \%$ \\
Lower Saxony & $1.1 \%$ & $1.6 \%$ & $0.2 \%$ & $1.9 \%$ & $3.9 \%$ & $0.0 \%$ \\
Bremen & $1.7 \%$ & $2.7 \%$ & $0.3 \%$ & $4.2 \%$ & $7.7 \%$ & $1.2 \%$ \\
North Rhine-Westphalia & $1.1 \%$ & $2.0 \%$ & $0.2 \%$ & $1.1 \%$ & $1.8 \%$ & $0.0 \%$ \\
Hesse & $1.9 \%$ & $3.6 \%$ & $0.2 \%$ & $1.5 \%$ & $2.9 \%$ & $0.0 \%$ \\
Rhineland-Palatinate & $1.8 \%$ & $3.1 \%$ & $0.3 \%$ & $2.1 \%$ & $3.9 \%$ & $0.1 \%$ \\
Baden-Wuerttemberg & $2.4 \%$ & $4.8 \%$ & $0.3 \%$ & $5.3 \%$ & $11.8 \%$ & $0.0 \%$ \\
Bavaria & $2.2 \%$ & $5.2 \%$ & $0.3 \%$ & $3.5 \%$ & $4.9 \%$ & $2.2 \%$ \\
Saarland & $1.4 \%$ & $2.4 \%$ & $0.3 \%$ & $2.2 \%$ & $4.0 \%$ & $0.7 \%$ \\
\hline \hline
\end{tabular}

Source: German Federal Returning Officer (www.bundeswahlleiter.de), own calculations.

\section{DESCRIPTIVE STATISTICS}

We start the empirical analysis with some descriptive statistics regarding our key variables. Table 1 provides descriptive statistics of the voting results for right-wing parties broken down by West German states. As can be seen, there is a substantial variance in the share of votes going to the far right. In federal elections, which are held roughly every four years, the mean percentage of votes going to right-wing parties was between 1.1 percent (in Lower Saxony and North Rhine-Westphalia) and 2.9 percent in Berlin over the period 1983-2008. In all federal elections, the far right received at least some votes in all states (the minimum is strictly positive). Right-wing parties received their largest vote share in Bavaria (5.2 percent in 1990, of which 5.0 percent went to the Republikaner).

On average, right-wing parties receive more votes in state elections than in federal elections. In most states, elections to state legislatures are also held about every four years, but are typically not synchronized with federal elections. Mean vote shares for the far right range between 1.1 percent (North Rhine-Westphalia) and 5.3 percent (Baden-Württemberg). In some state elections, none of the right-wing parties participated. Hence, the minimum vote received is strictly zero in some states. The maximum vote, however, is as high as 20.2 percent in the city state of Hamburg (2001; the Schill-Partei received 19.4 percent) and 11.8 percent in Baden-Württemberg (1992; 10.9 percent was given to the Republikaner). 
Table 2: Descriptive statistics

\begin{tabular}{lcccc}
\hline \hline & \multicolumn{2}{c}{ non-migrants } & \multicolumn{2}{c}{ migrants } \\
variable & $\begin{array}{c}\text { mean value / } \\
\text { share }\end{array}$ & $\begin{array}{c}\text { standard } \\
\text { deviation }\end{array}$ & $\begin{array}{c}\text { mean value / } \\
\text { share }\end{array}$ & $\begin{array}{c}\text { standard } \\
\text { deviation }\end{array}$ \\
\hline age & 41.1 & $(0.19)$ & 39.3 & $(0.28)$ \\
years of education & 11.6 & $(0.04)$ & 10.1 & $(0.05)$ \\
$\begin{array}{l}\text { net household income } \\
\text { p.c. (in Euro) }\end{array}$ & 965.1 & $(10.11)$ & 714.8 & $(11.78)$ \\
$\begin{array}{l}\text { married/cohabiting } \\
\text { number of children }\end{array}$ & 0.76 & & 0.78 & \\
$\begin{array}{l}\text { persons living in } \\
\text { household } \\
\text { household member in } \\
\text { need of care }\end{array}$ & 0.6 & $(0.01)$ & 1.0 & $(0.02)$ \\
share unemployed & 0.03 & $(0.02)$ & 3.4 & $(0.03)$ \\
share employed & 0.05 & & 0.02 & \\
share high-educated & 0.66 & & 0.11 & \\
\hline \hline
\end{tabular}

Source: SOEP, 1984-2006.

Note: Observations weighted by cross-sectional weights.

Table 2 shows some descriptive statistics of the sample. Since we restrict our attention to persons who are between 18 and 65 years old, the average age in our sample is 41.1 years for non-migrants, while migrants are, on average, almost two years younger. The average nonmigrant has 11.6 years of schooling (including vocational training). Migrants have attended schools for only 10.1 years. The statistics further show that non-migrants' net household income (divided by the number of household members) is about 35 percent higher than that of migrants. Migrants have more children and live in larger households than non-migrants. Moreover, their unemployment rate is higher and the employment rate lower. A larger share of non-migrants than of migrants is highly educated ( $>11$ years of schooling). The share of persons who are married or cohabitating as well as the share of people who are living with a household member in need of care are very similar between both subpopulations.

Table 3 shows the mean life satisfaction of migrants and non-migrants broken down by education. Within each educational group, non-migrants report higher life satisfaction scores than migrants (7.01 vs. 6.81 for the low-educated, and 7.21 vs. 6.95 for the highly educated). Education is positively related with life satisfaction among both migrants and non-migrants. The differences between the life satisfaction scores of any two of the four groups are all significant at the $1 \%$-level. 
Table 3: Mean life satisfaction scores, by education

\begin{tabular}{ccc}
\hline \hline & migrants & non-migrants \\
\hline \multirow{2}{*}{ Low Education } & 6.81 & 7.01 \\
& $(1.96)$ & $(1.89)$ \\
High Education & obs.: 34,927 & obs.: 88,320 \\
& 6.95 & 7.21 \\
& $(1.83)$ & $(1.67)$ \\
& obs.: 6,418 & obs.: 84,012 \\
\hline \hline
\end{tabular}

Source: SOEP, 1984-2006.

Note: Standard deviation in parentheses, observations weighted by cross-sectional weights.

The aim of our study is to illuminate how the prevalence of right-wing extremism and xenophobia affects the well-being of immigrants. Figure 1 makes a first pass by showing the mean life satisfaction of migrants and non-migrants, averaged over four-year periods from 1984 to 2006. As the figure shows, there appears to be a negative relationship between the share of right-wing votes at the state level and the mean life satisfaction of migrants in that state. Hence, the well-being of migrants is considerably lower in regions where right-wing parties perform successfully. An increase in the voting outcome of the far-right by 5 percentage points is associated with a reduction in life satisfaction by 0.5 points. In contrast, we do not find significant evidence for such an effect for the native-born population. Compared to the migrant population, the mean life satisfaction of non-migrants does not seem to be correlated with the share of votes given to right-wing parties in their region. 
Figure 1: Life satisfaction and right-wing extremism

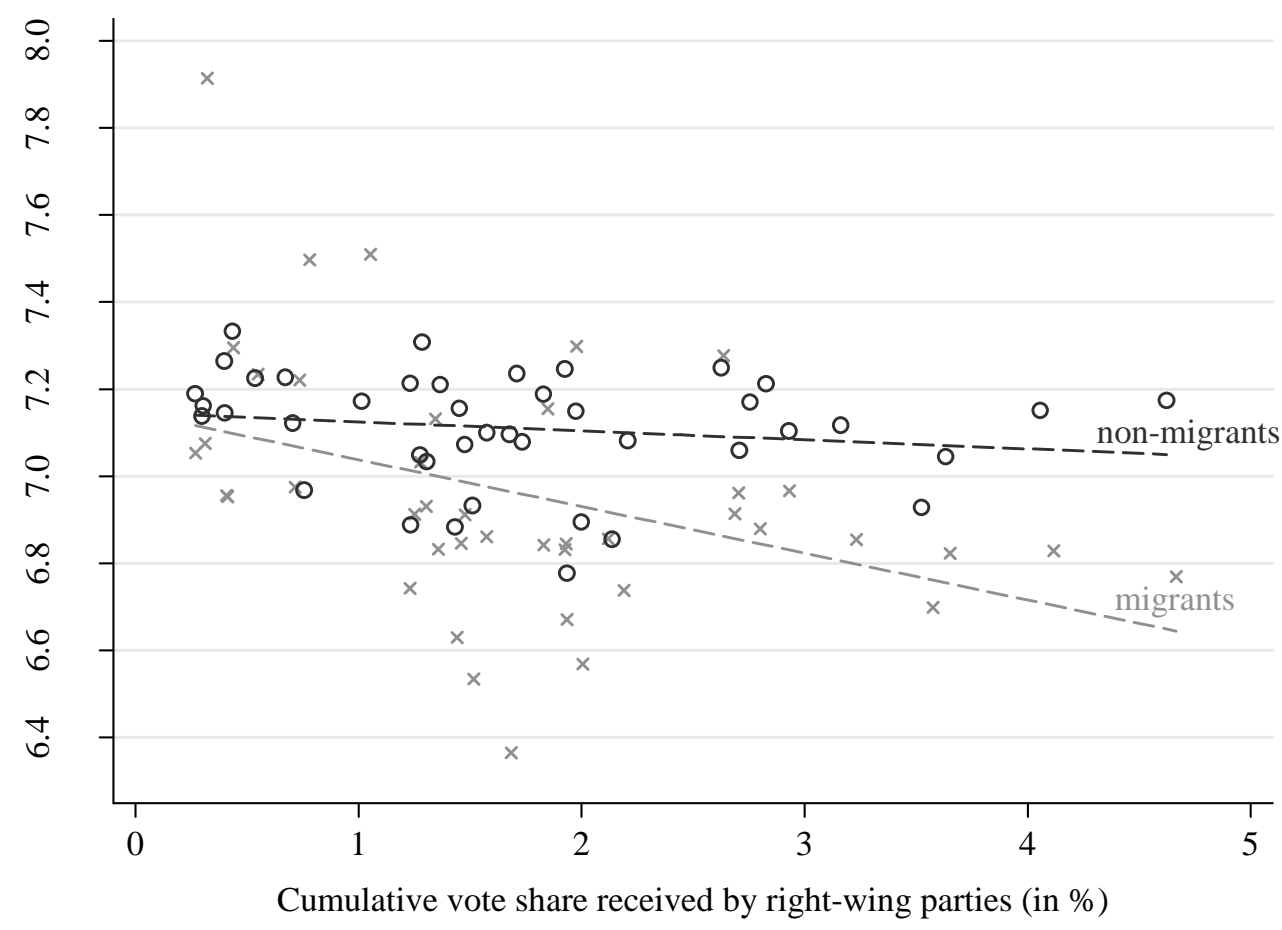

Source: SOEP, 1984-2006.

Note: Circles (crosses) denote the mean life satisfaction of non-migrants (migrants) and the vote share of right-wing parties in a particular West German state (excl. city states), averaged over the following periods: 1984-1987, 1988-1991, 1992-1995, 1996-1999, 2000-2003, and 2004-2006.

\section{REGRESSION RESULTS}

To separate the influence of the prevalence of right-wing extremism on well-being from that of other regional and individual factors, we conduct regression analyses. Table 4 contains the results from regressing individual life satisfaction on the share of right-wing votes, educational attainment, and a set of regional and individual characteristics (corresponding to equations (1) and (2)). The individual socio-demographic characteristics regarded in the estimations comprise the employment state (unemployment, out of labor force, selfemployed, part-time employment, public employment), the family situation (cohabitation or marriage, widowed, divorced, number of children, having a household member in need of care), the household net income per capita, and age (10-year age brackets). The regional variables considered should capture the effects of (local) economic conditions on life satisfaction, which has been shown to be relevant, e.g. by Luechinger et al. (2010). We control for GDP per capita, the unemployment rate and the crime rate at the state level. Since 
we are estimating separate regression for migrants and natives, our specifications allow for differentiated effects of these regional variables on the two groups.

We restrict our attention to federal elections, but discuss the effect of state elections later. We use an ordinary least squares regression with individual fixed effects because this allows us to interpret the results directly as marginal effects. The standard errors in the regressions are clustered by state and election period, as election results are aggregated at a higher level than is the dependent variable (see Moulton, 1990). ${ }^{4}$ The results shown in Columns 1 and 2 refer to equation (1), i.e. they do not differentiate between different levels of educational attainment. Our results strongly support our hypotheses that a higher prevalence of right-wing extremism in a region, approximated by the share of votes given to right-wing parties, reduces the life satisfaction of foreigners living in that region. The coefficient is substantially negative and statistically significant at the 5\%-level. Our results suggest that the life satisfaction of foreigners is reduced by 0.29 points if right-wing parties receive 10 percentage points more votes. Although such an increase in the share of right-wing votes might seem to be a rare event, it is similar to the magnitudes observed in state elections in Baden-Württemberg in 1992 (increase of 8.7 percentage points), Hamburg in 2001 (increase of 14.3 percentage points), or the East German state of Saxony-Anhalt in 1998 (increase of 12.2 percentage points).

\footnotetext{
${ }^{4}$ Clustering at the state level leads to virtually identical results.
} 
Table 4: Estimation results

\begin{tabular}{|c|c|c|c|c|}
\hline & \multicolumn{2}{|c|}{ Basic estimation } & \multicolumn{2}{|c|}{$\begin{array}{l}\text { Estimation with education } \\
\text { interaction }\end{array}$} \\
\hline & (1) & (2) & (3) & (4) \\
\hline & migrants & non-migrants & migrants & non-migrants \\
\hline Dependent variable & $\begin{array}{c}\text { Life } \\
\text { Satisfaction } \\
\end{array}$ & $\begin{array}{c}\text { Life } \\
\text { Satisfaction }\end{array}$ & $\begin{array}{c}\text { Life } \\
\text { Satisfaction } \\
\end{array}$ & $\begin{array}{c}\text { Life } \\
\text { Satisfaction }\end{array}$ \\
\hline Method & FE OLS & FE OLS & FE OLS & FE OLS \\
\hline \multicolumn{5}{|l|}{ Elections results } \\
\hline Right-wing votes & $\begin{array}{c}-2.875 * * \\
(1.394)\end{array}$ & $\begin{array}{l}-0.678 \\
(0.730)\end{array}$ & $\begin{array}{l}-2.154 \\
(1.494)\end{array}$ & $\begin{array}{l}-0.568 \\
(0.881)\end{array}$ \\
\hline $\begin{array}{l}\text { High Education * } \\
\text { Right-wing votes }\end{array}$ & & & $\begin{array}{c}-4.563 * * \\
(1.857) \\
\end{array}$ & $\begin{array}{r}-0.221 \\
(0.793) \\
\end{array}$ \\
\hline \multicolumn{5}{|l|}{ Other variables } \\
\hline Unemployed & $\begin{array}{c}-0.698 * * * \\
(0.044)\end{array}$ & $\begin{array}{c}-0.662 * * * \\
(0.026)\end{array}$ & $\begin{array}{c}-0.699 * * * \\
(0.044)\end{array}$ & $\begin{array}{c}-0.662 * * * \\
(0.026)\end{array}$ \\
\hline $\begin{array}{l}\text { log net } \mathrm{HH} \text { income } \\
\text { p.c. }\end{array}$ & $\begin{array}{c}0.386 * * * \\
(0.048)\end{array}$ & $\begin{array}{c}0.293 * * * \\
(0.017)\end{array}$ & $\begin{array}{c}0.386 * * * \\
(0.048)\end{array}$ & $\begin{array}{c}0.293 * * * \\
(0.017)\end{array}$ \\
\hline Cohabiting & $\begin{array}{l}0.094 \\
(0.059)\end{array}$ & $\begin{array}{c}0.199 * * * \\
(0.020)\end{array}$ & $\begin{array}{l}0.096 \\
(0.058)\end{array}$ & $\begin{array}{c}0.200 * * * \\
(0.020)\end{array}$ \\
\hline Married & $\begin{array}{l}0.250 * * * \\
(0.058)\end{array}$ & $\begin{array}{c}0.291 * * * \\
(0.028)\end{array}$ & $\begin{array}{c}0.249 * * * \\
(0.058)\end{array}$ & $\begin{array}{c}0.291 * * * \\
(0.028)\end{array}$ \\
\hline High education & $\begin{array}{c}-0.078 \\
(0.051)\end{array}$ & $\begin{array}{c}-0.061 * * \\
(0.023)\end{array}$ & $\begin{array}{l}0.028 \\
(0.064)\end{array}$ & $\begin{array}{c}-0.057 * \\
(0.031)\end{array}$ \\
\hline Other personal controls & yes & yes & yes & yes \\
\hline Individual fixed effects & yes & yes & yes & yes \\
\hline Time fixed effects & yes & yes & yes & yes \\
\hline $\mathrm{R}^{2}$ & 0.057 & 0.043 & 0.057 & 0.043 \\
\hline Observations & 37448 & 160520 & 37448 & 160520 \\
\hline
\end{tabular}

Source: SOEP 1984-2006.

Note: OLS regressions with individual and time fixed effects. Other personal controls include widowed, divorced, number of children, out of labor force, self-employed, part-time employment, public employment, 10-year age brackets, having a household member in need of care, and statelevel variables (GDP p.c., unemployment rate, crime rate). We abstain from presenting all coefficients of our control variables because the results are in line with previous studies (see Frey and Stutzer, 2002, Blanchflower and Oswald, 2004, or Frijters et al., 2004). Clustered standard errors (by state and election period) in parentheses. " denotes significance at the 10-percent-level, ${ }^{* *}$ at the 5-percent-level, ${ }^{* * *}$ at the 1-percent-level.

The results for non-migrants, however, show a different picture. The coefficient on rightwing votes is negative, but its size is much smaller and not statistically significant. Hence, there is no clear evidence for a relation between sympathy for right-wing political ideas and average life satisfaction among the native-born population. The difference between the estimated effects of right-wing votes on migrants and non-migrants is statistically significant at the 10-percent level. The coefficients on our control variables have the expected signs. 
Being unemployed significantly reduces life satisfaction, while receiving more income raises it. Being married is associated with a significantly higher life satisfaction than being single. While the results in Table 2 suggest that education is associated with higher life satisfaction, Table 4 shows that this positive effect disappears when we control for income and employment status. This suggests that education serves as a means to obtain more income and better employment prospects rather than being an end in itself. Even though we control for some state-level variables (GDP per capita, unemployment rate, crime rate), it is conceivable that other local factors affect subjective well-being and right-wing extremism simultaneously (supply of subsidized housing, quality of public schools, etc.). Assuming that such factors have a similar impact on non-migrants and migrants, our finding that there is no significant correlation between the life satisfaction of non-migrants and right-wing extremism suggests that such factors do not play a major role. ${ }^{5}$

We now turn to specification (2), which includes the interaction effects between right-wing votes and educational attainment (see Table 4, columns (3) and (4)). The non-interacted effect of right-wing votes on the life satisfaction of foreigners is negative (although smaller than in specification (1) and not statistically significant). The interaction term between right-wing votes and the dummy indicating high educational attainment is significantly negative. This suggests that, while the prevalence of right-wing extremism appears to be negative for all foreigners, this effect is much more pronounced for immigrants with a higher level of education. ${ }^{6}$ The magnitude of the estimated coefficients implies that when the vote share of right-wing parties goes up by 10 percentage points, the life satisfaction of low-educated foreigners falls by almost 0.21 points (about 3 percent of their average life satisfaction), while high-educated foreigners experience a drop of almost 0.67 points (about 10 percent of their average life satisfaction). We do not find any comparable effect for non-migrants. The less educated are not significantly affected by the election outcomes of right-wing parties and there does not seem to be a differential effect between the educational groups. The difference

\footnotetext{
${ }^{5}$ Contrary to the migrant population, voting results are not exogenous to non-migrants. If a lower life satisfaction leads to more support for right-wing extremist parties, however, this would imply that our estimate of the effect of right-wing votes on the life satisfaction of non-migrants is biased downwards. This strengthens our result that right-wing extremism affects migrants and non-migrants differently.

${ }^{6}$ We also estimated a full interaction model in which we interacted all individual and regional variables with people's level of education. The results correspond to the ones presented in Table 4. In particular, our finding that the negative impact of RW votes on well-being is stronger for high-educated migrants is supported.
} 
between the effects of right-wing votes on the life satisfaction of migrants and non-migrants is statistically significant for high-educated persons.

\section{Robustness checks}

To check the robustness of these findings, we also conduct our estimations using various alternative specifications (see Table A.1 in the Appendix). We chose to estimate our model using OLS for ease of interpretation. A dependent variable that is obtained on a scale with a fixed number of points, such as the measure of life satisfaction, would be better dealt with using ordered response models. Therefore, we also estimate specification (2) applying a probit-adjusted OLS (van Praag and Ferrer-i-Carbonell, 2004) and a conditional fixed effects logit regression (Ferrer-i-Carbonell and Frijters, 2004)). These alternative estimation techniques support our findings obtained with the basic OLS, although results obtained by the conditional fixed effect logit model have the expected signs and magnitudes, but are not statistically significant. This could be due to the information loss from having to reduce the 10-point satisfaction variable to a binary one. Extending our sample by also including all persons who are older than 65 does not change our results. Excluding interstate movers does not change our results either, so our results are not driven by interstate migration of persons between states with different levels of right-wing votes as compared to intrastate variations of the prevalence of right-wing extremism. The effect of right-wing voting on migrants' wellbeing is also significant when we look at elections to state legislatures instead of federal elections. The effects appear to be smaller than for federal elections, though. This suggests that federal elections are a better indicator of right-wing extremism or receive more public attention than elections at the state level. Splitting our sample in three (intermediate: 11-15 years of education; high: more than 15 years) instead of two education categories suggests that the effect of right-wing extremism on migrants' well-being is monotonically increasing in their level of education.

Right-wing votes are a rather indirect way of measuring the prevalence of xenophobia experienced by migrants. Its use is only justified if there are no better measures available. To check this, we also tested two alternatives. The first alternative measure is the number of politically motivated violent crimes conducted by right-wing extremists (Verfassungsschutz, 2008). The results in Table A.1 show that this measure is neither significantly correlated with the life satisfaction of migrants nor with that of non-migrants. The problem with crime data, however, is that such data are only available since 2001 in Germany. Before 2001, there was 
no official and comprehensive definition of what constitutes a right-wing crime, so that the data provided by local police authorities was unreliable and incomparable. In 2001, the government introduced a new statistical system to measure politically motivated crimes. Even the data collected under this new system were not perfectly comparable (Kubink, 2002). States differed with respect to how they classify crimes which are probably politically motivated (for example the public display of a swastika, which is illegal in Germany) but for which the offender cannot be identified. In some states, the default was "not politically motivated" until the offender is caught and his motivation was revealed, while in other states the default was "politically motivated" until proven otherwise. Only in 2008 did the German states agree on a consistent procedure. Due to these problems, we think that, at least in the case of Germany, data on right-wing extremist crimes are a less reliable indicator of xenophobia than right-wing vote shares.

The second alternative measure we tested is based on the SOEP question whether somebody is "worried about immigration". We calculated the share of German citizens with no migration background in each state who reported to be somewhat or very worried about immigration. The impact of this variable on the life satisfaction of migrants is not statistically significant. We do not want overemphasize the statistical power of this test for the question at hand. First, this question has been asked in the SOEP only in the last seven of the available 23 waves. Second, to be worried about immigration does not necessarily imply to be racist or xenophobic. Overall, we believe that right-wing vote shares provide the best approximation to the extent of xenophobia in a region.

In Table 5, we stratify our estimations by gender. The results reveal that the negative effect of right-wing extremism on migrants' life satisfaction seems to be driven by the reaction of men, not by that of women. Various reasons might be responsible for this difference. One might suspect that high education and gender are simply proxies for personal economic conditions, in particular of one's labor market attachment. By controlling for employment status and the interaction of an employment dummy and the share of right-wing votes, we show that employed men seem to be affected more strongly than non-working men (although the difference is not statistically significant). The interaction effect for women is quantitatively much smaller and not significant. The education interaction for men stays large and significant. Hence, to be employed seems to matter for the strength of the impact of rightwing extremism on migrants' well-being for men, but it does not explain the general gender difference in our findings. 
Table 5: Gender differences

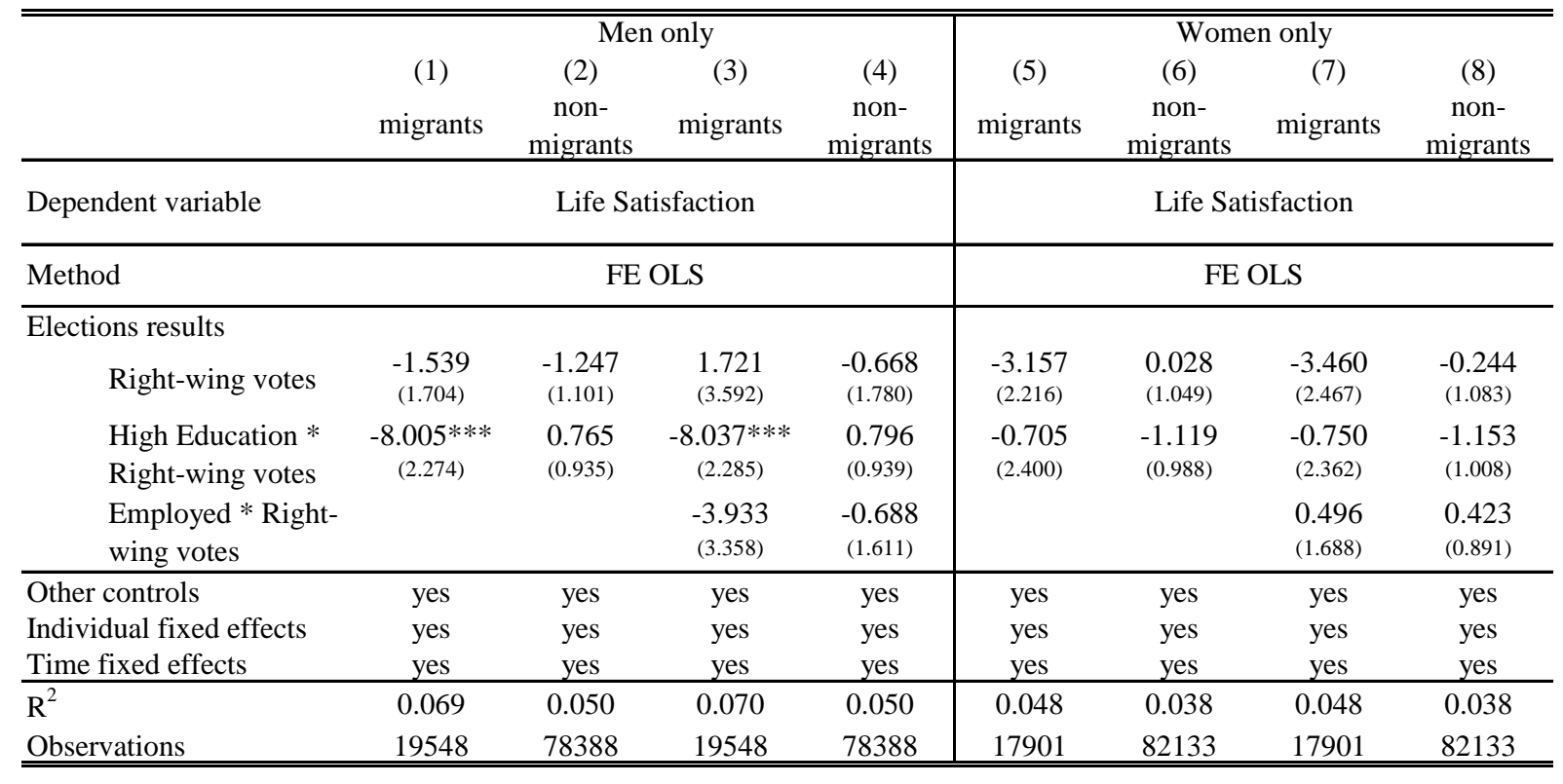

Source: SOEP 1984-2006.

Note: OLS regressions with individual and time fixed effects. All regressions contain the same control variables as in Table 4. Clustered standard errors (by state and election period) in parentheses. ${ }^{*}$ denotes significance at the 10-percent-level, ${ }^{* *}$ at the 5-percent-level, ${ }^{* * * *}$ at the 1 percent-level.

Another reason why female migrants are less affected by regional right-wing extremism could be that the victims of right-wing crimes are more often males than females. In their analysis of political crimes in the state of Northrhine-Westphalia, Willems and Steigleder (2003) report that the probability of becoming the victim of a violent xenophobic crime was twice as high for men as for women. If foreign men have to be more afraid to become a crime victim, this could explain part of this differential effect.

The gender difference could also originate from the stronger political interest of men in the migrant population. 30 percent of male migrants in our sample report to have a strong or very strong interest in political affairs, whereas this is only the case for 13 percent of female migrants. Among immigrants, only 24 percent of all men but 43 percent of all women are not at all interested in politics. Less political interest might make female immigrants less aware of changes in political attitudes among the native-born population and thus lead to a smaller impact on their subjective well-being.

\section{Behavioral implications}

Our argument that regional xenophobia makes a region less attractive for high-skilled immigrants, and thus impairs selective migration policies, rests on the assumption that life 
satisfaction matters for migration decisions. This assumption has intuitive appeal because one would expect people's migration decisions to be driven by their desire to "pursue happiness". Indeed, Blanchflower and Shadforth (2009) who show that the propensity to migrate from Eastern Europe to the UK is negatively correlated with mean life satisfaction in the migrants' home countries. The correlation with life satisfaction is stronger than that with GDP per capita. Nevertheless, it is difficult to provide a direct empirical test of this assumption using micro-data because such data typically does not contain information on actual migration decisions. In case of the SOEP, we only observe individuals while participating in the panel. If they drop out, it might be because they died, moved to an unknown destination (domestically or abroad), or refused to continue participating for other reasons. Hence, it is not possible to estimate the rate at which migrants leave the country convincingly. Likewise, we do not observe whether potential migrants abstain from moving to Germany.

Table 6: Migration intentions

\begin{tabular}{lcccc}
\hline \hline Dependent variable & \multicolumn{4}{c}{ Desire to stay in Germany forever $(1=$ yes; 0 = no) } \\
\hline Method & logit & cond. FE logit & logit & cond. FE logit \\
\hline Elections results & $(1)$ & $(2)$ & $(3)$ & $(4)$ \\
\multicolumn{1}{c}{ Life satisfaction } & $0.072^{* * *}$ & $0.104^{* * *}$ & & \\
High Education $*$ & $(0.007)$ & $(0.012)$ & & \\
life satisfaction & $0.074^{* * *}$ & 0.015 & & \\
\multicolumn{1}{c}{ Right-wing votes } & $(0.017)$ & $(0.030)$ & & -1.698 \\
$\quad$ & & & -2.865 & $(9.363)$ \\
$\quad$ High Education * & & & $(4.388)$ & -0.182 \\
$\quad$ Right-wing votes & & & -2.670 & $(29.579)$ \\
\hline Other controls & yes & yes & yes & yes \\
Individual fixed effects & no & yes & no & yes \\
Time fixed effects & yes & yes & yes & yes \\
\hline Log likelihood & -23817 & -10002 & -23704 & -9950 \\
Observations & 37124 & 25336 & 36751 & 25080 \\
\hline \hline
\end{tabular}

Source: SOEP 1984-2006.

Note: The sample includes migrants only. All regressions contain the same control variables as in Table 4. Clustered standard errors (by state and election period) in parentheses (columns 3 and 4). ${ }^{*}$ denotes significance at the 10-percent-level, ${ }^{* *}$ at the 5-percent-level, ${ }^{* * *}$ at the 1-percentlevel.

To illustrate that life satisfaction matters for migration decision, we make use of information on migration intentions. In the SOEP, respondents who are not German citizens since birth are asked every year "Do you want to stay in Germany forever?", to which they can answer either "yes" or "no". Using the sample of migrants, we regress the intention to stay on the same range of personal characteristics as before and add individual life satisfaction to the regressors. Our results show that life satisfaction is positively correlated with the 
intention to stay in Germany (Table 6). In the cross-section, we find a positive interaction with education, which even strengthens the argument that the deterring effects of right-wing extremism are especially strong for high-skilled migrants. When accounting for fixed effects, however, the interaction effect disappears. Nevertheless, life satisfaction remains a strong correlate of migration intentions. We also regress migration intentions on right-wing votes. The signs of the estimated coefficients indicate that an increase in the number of right-wing votes decreases the probability that a migrant intents to stay in Germany, but they lack statistical significance.

In general, the results show that an increase in the prevalence of right-wing attitudes and xenophobia reduces life satisfaction of migrants, and in particular of male migrants, noticeably. The results are robust to changes in the estimation method applied and to variations in the sample. The negative effects of right-wing extremism on the well-being of migrants are even more pronounced for highly educated migrants. We do not find evidence that the same relationship holds for the native-born population.

\section{CONCLUSION}

To cope with demographic change and to fill urgent shortages on their labor markets, aging economies rely on the inflow of young, well-educated migrants. To be attractive for such workers, it is not enough for countries to offer high wages and fast immigration processes. At least as important is that migrants can expect to move to a safe and open-minded society in which they can feel welcome and are able to enjoy a higher quality of life than in their country of origin. Xenophobia and other hostile attitudes towards migrants and other ethnic minorities among the native-born population, however, could constitute a strong deterrent to economically desirable migration (cf. the evidence provided by Bussmann and Werle 2004).

In this paper, we have analyzed the regional prevalence of anti-foreign sentiments expressed in right-wing voting behavior on the life satisfaction of migrants in that region. Using individual panel data for Germany from 1984 to 2006, our estimates indicate that the life satisfaction of migrants decreases when the right-wing extremism in their region of residence rises, as approximated by the vote share received by political parties of the extreme right in elections to federal and state parliaments. When distinguishing between different skill groups, we find that the better-educated migrants react more strongly to shifts in right-wing voting behavior than those with lower levels of education. As a possible explanation for this pattern, we suspect that better-educated immigrants have a stronger desire to identify with and 
integrate in their host country, resulting in stronger disappointment and frustration if they the native-born population reveals negative perceptions to immigration as expressed in an increasing share of right-wing votes. This presumption is also supported by Fan and Stark (2007) who show that the effort of assimilation and integration increases with economic similarity between migrants and natives. If life satisfaction is a decisive variable in the choice of regions people want to move to, work in, and spend their life in, an increased prevalence of right-wing behavior may frighten off foreigners, with potentially negative economic consequences for the region shunned by high-skilled migrants. These results suggest that recent attempts to make immigration more attractive to the high-skilled are ill-fated if they do not simultaneously address the question of how to reduce right-wing attitudes among the native-born population.

\section{References}

Bauer, Thomas K., Deborah Cobb-Clark, Vincent A. Hildebrand and Mathias Sinning (2011). A Comparative Analysis of the Nativity Wealth Gap, Economic Inquiry. 49: 989-1007.

Beutin, Ricklef, Marcel Canoy, Anna Horvath, Agnes Hubert, Frédéric Lerais, Peter Smith and Myriam Sochacki (2006). Migration and Public Perception. Report. Brussels: Bureau of European Policy Advisers, European Commission.

Blanchflower, David G. and Andrew J. Oswald (2004). Well-being over time in Britain and the USA, Journal of Public Economics. 88(7-8): 1359-1386.

Blanchflower, David G. and Chris Shadforth (2009). Fear, Unemployment and Migration, The Economic Journal. 119(535): F136-F182.

Borjas, George (1985). Assimilation, Changes in Cohort Quality, and the Earnings of Immigrants, Journal of Labor Economics. 3(4): 463-489.

Bussmann, Kai-D. and Markus Werle (2004). Fremdenfeindlichkeit und rechte Gewalt: Standortnachteil Ost, Neue Kriminalpolitik. 16(3): 96-99.

Card, David, Christian Dustmann and Ian Preston (2005). Understanding attitudes to immigration: The migration and minority module of the first European Social Survey. CREAM Discussion Paper No. 03/05, London.

Carlsson, Frederik and Olof Johansson-Stenman (2010). Why Do You Vote and Vote as You Do?, Kyklos. 63(4): 495-516.

Chiswick, Barry R. (1978). The Effect of Americanization on the Earnings of Foreign-born Men, Journal of Political Economy. 86(5): 897-921.

Constant, Amelie and Klaus F. Zimmermann (2005). Immigrant Performance and Selective Immigration Policy: A European Perspective, National Institute Economic Review. 194: 94-105.

Dustmann, Christian and Ian Preston (2001). Attitudes to Ethnic Minorities, Ethnic Context and Location Decisions, Economic Journal. 111 (April): 353-373. 
Dustmann, Christian and Ian Preston (2005). Is Immigration Good or Bad for the Economy? Analysis of Attitudinal Responses, Research in Labor Economics. 24: 3-34.

Falk, Armin, Andreas Kuhn and Josef Zweimüller (2011). Unemployment and Right-Wing Extremist Crime, Scandinavian Journal of Economics. 113(2): 260-285.

Fan, C. Simon and Oded Stark (2007). A Social Proximity Explanation of the Reluctance to Assimilate, Kyklos. 60 (1): 55-63.

Ferrer-i-Carbonell, Ada and Paul Frijters (2004). How Important is the Methodology for the Estimates of the Determinants of Happiness?, Economic Journal. 114 (July): 641-659.

Fertig, Michael and Christoph M. Schmidt (2011). Attitudes towards foreigners and Jews in Germany: identifying the determinants of xenophobia in a large opinion survey, Review of Economics of the Household. 9(1); 99-128.

Frey, Bruno S. and Alois Stutzer (2002). What Can Economists Learn from Happiness Research?, Journal of Economic Literature. 40(2): 402-435.

Frijters, Paul, John P. Haisken-DeNew and Michael A. Shields (2004). Investigating the Patterns and Determinants of Life Satisfaction in Germany Following Reunification, Journal of Human Resources. 39 (3): 649-674.

Guven, Cahit (2011). Are Happier People Better Citizens?, Kyklos. 64 (2): 178-192.

Haisken-DeNew, John P. and Markus Hahn (2006). PanelWhiz: A Flexible Modularized Stata Interface for Accessing Large Scale Panel Data Sets. http.//www.panelwhiz.eu, mimeo.

Ivarsflaten, Elisabeth (2005). The vulnerable populist right parties: No economic realignment fuelling their electoral success, European Journal of Political Research. 44: 465-492.

Ivarsflaten, Elisabeth (2008). What Unites Right-Wing Populists in Western Europe? ReExamining Grievance Mobilization Models, in: Seven Successful Cases, Comparative Political Studies 41(1): 3-23.

Kroh, Martin and Martin Spieß (2006). Documentation of Sample Sizes and Panel Attrition in the German Socio Economic Panel (SOEP) 1984 - 2005. DIW Data Documentation 15, Berlin: DIW.

Krueger, Alan B. and Jörn-Steffen Pischke (1997). A statistical analysis of crime against foreigners in unified Germany, Journal of Human Resources. 32: 182-209.

Kubink, Michael (2002). Rechtsextremistische und fremdenfeindliche Straftaten, Zeitschrift für Rechtspolitik. 07/2002: 308-312.

Land, Kenneth C., Patricia L. McCall and Lawrence E. Cohen (1990). Structural Covariates in Homicide Rates: Are There Any Invariances Across Time and Social Space?, American Journal of Sociology. 95(4): 922-963.

Liebig, Thomas (2007). The Labour Market Integration of Immigrants in Germany. OECD Social, Employment, and Migration Working Papers No. 47, Paris: OECD.

Luechinger, Simone, Stephan Meier and Alois Stutzer (2010). Why Does Unemployment Hurt the Employed? Evidence from the Life Satisfaction Gap Between the Public and the Private Sector, Journal of Human Resources. 45(4): 998-1045.

Moulton, Brent R. (1990). An Illustration of a Pitfall in Estimating the Effects of Aggregate Variables on Micro Units, The Review of Economics and Statistics. 72(2): 334-38.

OECD (2007). International Migration Outlook 2007, Paris: OECD. 
Safi, Mirna (2010). Immigrants' Life Satisfaction in Europe: Between Assimilation and Discrimination, European Sociological Review. 26(2): 159-176.

Siedler, Thomas (2011). Parental Unemployment and Young People's Extreme Right-Wing Party Affinity: Evidence from Panel Data, Journal of the Royal Statistical Society: Series A. 174(3): 737-758.

Statistisches Bundesamt (2006). Bevölkerung Deutschlands bis 2050. Wiesbaden.

Statistisches Bundesamt (2008). Bevölkerung und Erwerbstätigkeit. Ausländische Bevölkerung. Fachserie 1 Reihe 2, Wiesbaden.

van Praag, Bernard M. S. and Ada Ferrer-i-Carbonell (2004). Happiness quantified. A satisfaction calculus approach. Oxford: Oxford University Press.

Verfassungsschutz (2008). Verfassungsschutzbericht 2008, Berlin: Bundesministerium des Innern.

Willems, Helmut and Sandra Steigleder (2003). Youth Conflict or Hate Crime? Constellations of Perpetrators and Victims in Xenophobic Violence (in German), Journal of Conflict and Violence Research. 5(1): 5-28.

World Bank (2006). Global Economic Prospects 2006. Economic Implications of Remittances and Migration, Washington: World Bank. 


\section{APPENDIX}

Table A.1: Robustness checks

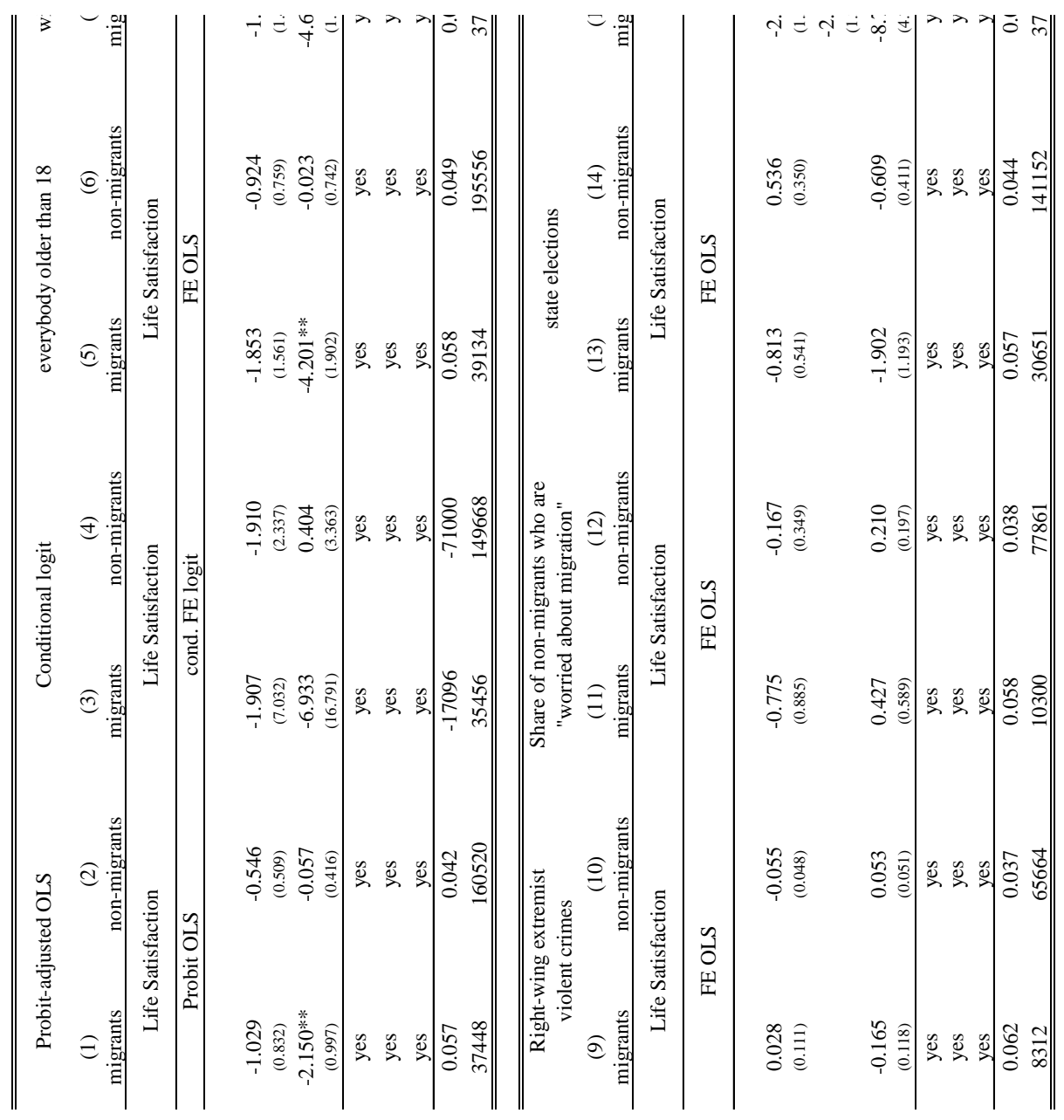

Source: SOEP 1984-2006.

Note: All regressions contain the same control variables as in Table 4. Right-wing extremism is measured by right-wing votes (columns 1-8 and 13-16), the number of right-wing extremist violent crimes (per 100.000 inhabitants) at the state level (columns 9 and 10), or the share of nonmigrants reporting to be worried about migration (columns 11 and 12; source: SOEP). Clustered standard errors (by state and election period in columns 1-8 and 13-16; state and year in columns 9-12) in parentheses. ${ }^{*}$ denotes significance at the 10-percent-level, ${ }^{* *}$ at the 5-percent-level, ${ }^{* * *}$ at the 1-percent-level. 